\author{
ERLA ERLENDSDÓTTIR \\ HÁSKÓLI ÍSLANDS
}

\title{
Avókadó og maís Orð með rætur í frumbyggjamálum spænsku Ameríku
}

\section{Inngangur}

Q egja má að landafundir Spánverja á 15. og 16. öld hafi að mörgu Oleyti markað tímamót í mataræði Evrópubúa. Frá nýfundinni veröld bárust alls kyns ávextir, rótarhnýði, korn og kryddjurtir, nytjajurtir sem í pá tî̉ voru með öllu ópekktar í Gamla heiminum. Meðal peirra voru til að mynda avókadó, maís, kartöflur og tómatar, ásamt papaja, gvava, chilipipar, kakó og súkkulaði.

Pegar Kristófer Kólumbus sneri heim til Spánar frá nýfundnum eyjum í Karíbahafi árið 1493 hafði hann ýmsar jurtir með í farteskinu, meðal annars maís og tóbak. ${ }^{1}$ Á fyrri hluta 16. aldar komu spænskir sæfarar og landafundamenn með tómata, avókadó, chilipipar, kakó og súkkulaði frá Mexíkó. Rösklega áratug síðar kynntust Spánverjar kartöflurækt í ríki Inkanna í Andesfjöllum og höfðu rótarhnýðið með sér til Evrópu. ${ }^{2}$

Í spænsku voru ekki til orð yfir allt hið nýja sem bar fyrir augu aðkomumanna á framandi slóðum. Til að byrja með brugðu peir á pað ráð að grípa til orða úr eigin tungumáli og var maís til dæmis

Cristóbal Colón, Los cuatro viajes. Testamento, ritstj. Consuelo Varela, Madrid: Alianza Editorial, 1996, bls. 234.

2 Manuel Lobo Cabrera og Fernando Bruquetas de Castro, "La papa: el verdadero tesoro de los Incas", Documentos del archivo histórico provincial de Las Palmas, Las Palmas: Archivo Histórico Provincial de Las Palmas, 2015, http://www.gobiernodecanarias.org/opencms8/export/sites/cultura/archivolaspalmas/.content/actualidad/masinfo/La_papax_el_verdadero_tesoro_de_los_Incas.pdf [sótt 15 . desember 2018]. 
kallaður trigo de las Indias ${ }^{3}$, korn frá Indíum', avókadó var líkt við gráfíkju ${ }^{4}$ en fékk sîđar heitið pera, chili kallaðist piparjurt og par fram eftir götunum. ${ }^{5}$ Pegar fram liðu stundir fóru aðkomumenn að nota orð og heiti úr tungumálum frumbyggja, oft ásamt skýringum, og tóku par með upp mörg ný orð í spænsku. Pessi tökuorð bárust með peim til Gamla heimsins ýmist í ræðu eða riti, í fyrstu til Spánar en með tíd og tíma bárust pau yfir í önnur Evrópumál, oft ásamt afurðinni eða fyrirbærinu sem pau vísuðu til. Leið orðanna var greið, pví pað voru ekki til orð yfir hið nýja í viðtökumálunum en nýjungar af öllu tagi kalla á ný hugtök og heiti.

Flest orðin sem voru tekin upp í spænsku eftir komu Spánverja til Nýja heimsins eru úr taíno, máli indíána á Stóru-Antillaeyjum í Karíbahafi, nahuatl, tungumáli Asteka í Mexíkó, og quechua, tungumáli Inka í Suður-Ameríku. En einnig hafa ratað inn í málið orð úr aravak, aimara, maya, tupí og guaraní. Önnur indíánamál lögðu til stöku orð. ${ }^{6}$ Pað kemur ekki á óvart að petta hlutfall sé svipað í öðrum evrópskum viðtökumálum.

Aðkomuorðin úr frumbyggjamálunum heyra undir ákveðin merkingarsvið. Flest eru pau heiti á plöntum, jurtum, trjám og ávöxtum. Önnur falla undir dýraheiti, pá eru orð sem lúta að veðurfari, siglingum, fatnaði og náttúrufyrirbærum auk orða yfir ýmsar afurðir, svo að helstu svið séu nefnd.

3 José de Acosta, Historia natural y moral de las Indias, México: Fondo de Cultura Económica, 2006 [1590] bls. 190. Acosta greinir frá pví að Ítalir kalli maís korn frá Tyrklandi eða tyrkneskt korn.

4 Fray Toribio de Benavente o Motolinia, Historia de los indios de la Nueva España, ritstj. Edmundo O’Gorman, México: Editorial Porrua, 1984, bls. 157.

5 Um petta má lesa frekar í Emma Martinell Gifre, La comunicación entre españoles e indios: palabras y gestos, Madrid: Mapfre, 1992. Antonio Torres Torres, Procesos de americanización del léxico bispánico, Valencia: Universitat de Vàlencia, 2004. Sami höfundur, „Los procesos de denominación de la nueva realidad americana“, De América a Europa. Denominaciones de alimentos americanos en lenguas europeas, ritstj. Erla Erlendsdóttir, Emma Martinell og Ingmar Söhrman, Frankfurt am Main/ Madrid: Iberoamericana-Vervuert, 2017, bls. 35-46.

6 José María Enguita Utrilla, Para la bistoria de los americanismos léxicos, Frankfurt am Main/Berlin/ Bern/Bruxelles/New York/Oxford/Wien: Peter Lang, 2004. Tomás Buesa Oliver og José María Enguita Utrilla, Léxico del español de América: su elemento patrimonial e indígena, Madrid: Mapfre, 1992. Emma Martinell Gifre, La comunicación entre españoles e indios: palabras y gestos, Madrid: Mapfre, 1992. F. Ligorred, Paraules de les llengües d'Amèrica, Barcelona: Generalitat de Catalunya, 1992. Pedro Henríquez Ureña, Para la historia de los indigenismos, Buenos Aires: Facultad de Filosofía y Letras de la Universidad de Buenos Aires, 1983. Miguel León-Portilla, „Otro testimonio de aculturación hispano-indígena: Los nahuatlismos en el castellano de España", Revista de Antropología Americana v. XI (1981), bls. 219-243. Hugo A. Mejías, Préstamos de lenguas indígenas en el español americano del siglo XVII, México: Universidad Nacional Autónoma de México, 1980. 
Í pessari grein verður fjallað um tvö orð sem eiga rætur í tungumálum frumbyggja spænsku Ameríku og hafa verið tekin upp í ýmis Evrópumál; hér verður sjónum einkum beint að norðurgermönsku tungumálunum: dönsku, íslensku, norsku og sænsku. Orðin sem um ræðir eru af merkingarsviðinu nytjajurtir, abuacatl ,avókadó‘ og mabiz ,maís', og koma upprunalega úr nahuatl-máli í Mexíkó og taíno-máli sem var talað á Antillaeyjum. Ætlunin er að varpa ljósi á sögu ${ }^{8}$ orðanna, p.e. uppruna peirra, fyrstu rituðu heimildir um pau, og rekja leið peirra frá upprunamáli yfir í spænsku og önnur viðtökumál og áfram til viðtökumálanna sem hér eru í brennidepli. Ekki er hugmyndin að fjalla ítarlega um form- eða merkingarbreytingar orðanna í viðtökumálunum pótt lauslega verði drepiðá breytingar sem pau kunna hafa tekið á ferð sinni frá einu tungumáli til annars og aðlögun peirra að málkerfi fyrrnefndra viðtökumála.

Orðin sem urðu fyrir valinu eru hluti af orðaforða daglegs lífs í viðtökumálunum sem um ræðir. Fyrir vikið má gera ráð fyrir að pau komi fyrir í helstu orðabókum viðkomandi tungumála, sögulegum orðabókum, orðsifjabókum og peim ýmsu gagnagrunnum sem eru aðgengilegir á vefsíðum, eða í seðlasöfnum, stofnana sem hafa með orð- og orðabókarannsóknir að gera, og par var leitað fanga. Einnig hafa frumheimildir verið skoðaðar, einkum pýðingar og rit sem lúta að nýrri veröld í Vesturheimi. Pess má geta að orð úr tungumálum frumbyggja í spænsku Ameríku komu yfirleitt inn í viðtökumálin í ritmáli, öðrum heimildum um orðin er augljóslega ekki til að dreifa, en elstu ritdæmi margra orðanna í norrænum málum er að finna, líkt og í öðrum evrópskum viðtökumálum, í ritum af ýmsum toga. Má par nefna til dæmis pýðingar, ferðasögur, fræðitexta, matreiðslubækur, orðasöfn og orðabækur, tímarit og dagblöð.

Efnisskipan greinarinnar er pannig að í öðrum kafla eru áðurnefnd orð kynnt til sögunnar. Í kafla 2.1 er fjallað um orðið avókadó. Pá er sjónum beint að maís í kafla 2.2 og greininni lýkur svo með samantekt og lokaorðum.

\footnotetext{
7 Hér er átt við pann hluta Ameríku par sem nú er töluð spænska, til aðgreiningar frá peim svæðum í Ameríku par sem töluð er portúgalska, franska, enska og hollenska.

8 Nálgunin er menningar- og orðsöguleg.
} 


\section{Avókadó og maís}

Í köflunum sem hér fara á eftir verður, eins og áður sagði, fjallað um tvö orð sem rekja má til tungumála frumbyggja í spænsku Ameríku. Fyrst er sjónum beint að avókadó sem er upprunalega úr tungu indíána í Mexíkó, og alla jafna talið eiga ræur í orðmyndinni abuacatl í nahuatl, tungumáli hinna fornu Asteka. ${ }^{9}$ Pá er vikið að orðinu maís sem er rakið til mabiz í taíno, tungumáli frumbyggja sem var talað á eyjum í norðanverðu Karíbahafi pegar Evrópubúar komu pangað í lok 15. aldar. Petta tungumál, sem telst til arawakmálaættarinnar, er nú útdautt. ${ }^{10}$

Orðin sem hér eru til umfjöllunar heyrðu spænskir sæfarar og landvinningamenn af vörum frumbyggja í Nýja heiminum um aldamótin 1500 og á fyrstu áratugum 16. aldar. Ekki leið á löngu uns pau tóku að slæðast inn í spænska texta af ýmsu tagi sem fjölluðu á einn eða annan hátt um hina nýfundnu veröld. Pessir textar voru prentaðir á Spáni og seinna pýddir á önnur Evrópumál. Pýðingar á frásögnum Spánverja af Nýja heiminum voru ekki einungis farvegur fyrir ýmsan fróðleik um dýra- og náttúrufar framandi heimsálfu, íbúa hennar og menningu, heldur einnig fyrir orð úr tungumálum frumbyggjanna.

Textar og kronikur spænskra annálaritara og trúboða ásamt sendibréfum landafunda- og landvinningamanna á vegum spænsku krúnunnar eru í flestum tilvikum fyrstu rituðu heimildir par sem orð af pessum uppruna koma fyrir og ennfremur elsta ritaða form peirra, pví frumbyggjar áttu sér ekki ritmál. ${ }^{11}$ Fyrir vikið er hvort tveggja, ritháttur og hljóðfræðileg gerð orðanna, í rauninni spænskt, pað er að segja að hljóðasambönd orðanna sem um ræðir voru spænsk en ekki til að mynda taínísk, nahuatlísk eða quechuísk, o.s.frv. Pau voru, að segja má, í spænskum búningi pegar pau bárust inn í önnur tungumál og pannig voru pau allt par til pau féllu smám saman að hljóðkerfi og beygingarreglum viðtökumálanna. Í flestum

\footnotetext{
$9 D N=$ Diccionario del nábuatl en el español de México, ritstj. Carlos Montemayor, México: UNAM, 2009, bls. 22. Tomás Buesa Oliver og José María Enguita Utrilla, Léxico del español de América: su elemento patrimonial e indígena, bls. 84.

10 Sama rit, bls. 106.

11 Inkar notuðu quipu, eða hnútaletur, til að skrá helstu atburði. Mayar og Astekar notuðu myndletur.
} 
tilfellum hefur spænska miðlað orðunum til viðtökumálanna, eins og áđur sagði, en í mörgum tilvikum hafa pau haft viðkomu í fleiri Evrópumálum áđur en pau bárust norður á bóginn. Pað hefur leitt til pess að aðkomuorðin fengu jafnvel franskt, pýskt eða enskt yfirbragð ádur en pau voru tekin upp í norrænar tungur.

\subsection{Avókadó}

Avókadó, perulaga aldin lárperutrésins (lat. Persea americana), hefur einnig verið kallað lárpera eða grcenaldin á íslensku. ${ }^{12}$ Lárperutréð, sem er upprunnið í Mið- og Suður-Ameríku, og ávöxtur pess bárust til Gamla heimsins með spænskum landkönnuðum og landvinningamönnum pegar á 16. öld. Í dag er aldin plöntunnar pekkt fæða og á borðum manna víða um heim.

Orðið abuacatl er úr nahuatl, ${ }^{13}$ tungumáli frumbyggja í Mexíkó, og merkir ,avókadó‘. Ekki er úr vegi að geta pess að í fleirtölu er orðið notað í merkingunni ,eistu' meðal nahuatl-mælandi og má gera pví skóna að um myndlíkingu sé að ræða, hins vegar er ekki ljóst hvort petta er upprunaleg merking orðsins eða sîðari tíma merkingarvíkkun. ${ }^{14}$ Elsta ritdæmi með orðinu er að finna í Historia de los indios de la Nueva España (Saga indíána á Nýja Spáni) eftir Toribio de Benavente, öðru nafni Motolinía. Hann var trúboði af fransiskanareglunni og sî̉ar sagnaritari í Nýja heiminum. ${ }^{15}$ Hann er talinn hafa ritað verk sitt í Mexíkó á árunum 1536-1541. ${ }^{16}$ Í 9. kafla skrifar Motolinía: „Meðal aldina sem er að finna í pessum fjallahéruðum, og reyndar í öllu landinu, er eitt sem kallast aua-

$12 I ́ A O=$ Íslenska alfrađiorłabókin, Reykjavík: Örn og Örlygur, 1990, bls. 359. MíM, s. v. avókadó. Einungis avókadó og lárpera koma fyrir í Íslenskri orðabók. ÍO = Íslensk orłabók, ritstj. Mörður Árnason, Reykjavík: Edda, bls. 59, 875. ÍB = Stofnun Árna Magnússonar í íslenskum fræðum, İðordabanki Árnastofnunar http://www.ordabanki.hi.is/wordbank/search [sótt 15. desember 2018], s. v. avókadó.

13 DN, bls. 22.

14 Sama rit. Marcos A. Morínigo, Diccionario del español de América, Madrid: Anaya \& Mario Muchnik, 1996, bls. 19-20.

15 Fray Toribio de Benavente «Motolinía», Historia de los indios de la Nueva España, ritstj. Mercedes Serna Arnaiz og Bernat Castany Prado, Madrid: Real Academia Española - Centro para la Edición de los Clásicos Españoles, 2014, bls. 10, http://www.rae.es/publicaciones/obras-academicas/bcrae/ historia-de-los-indios-de-la-nueva-espana-de-fray-toribio-de [sótt 15. desember 2018].

16 CORDE = Real Academia Española: Banco de datos (CORDE) [en línea]. Corpus diacrónico del español. http://www.rae.es [sótt 15. desember 2018]. 
catl. “17 Hann líkir ávextinum við stórar gráfíkjur sem séu á bragðið eins og furuhnetur. Pegar hann víkur að stærð og mismunandi gerðum aldinsins segir hann pað vera „á stærð við stórar perur“ og „svo bragðgott“ að betri ávöxt sé vart að finna á Nýja Spáni. Í pessari sömu málsgrein kemur orðið fyrir með spænskri fleirtöluendingu, -es: auacates. ${ }^{18}$ Motolinía tekur pví strax til við að laga orðið að málkerfi spænskunnar par sem hljóðskipunarreglur leyfa ekki hljóðasambandið - $t l$ og fyrir vikið hefur samhljóðið - $l$ verið skrifað - $e$, eins og mörg eldri ritdæmi orðsins sýna. Önnur kunn tökuorð sem lúta sömu reglu eru xocolatl sem varð chocolate ,súkkulaði', og tomatl sem varð tomate ,tómatur ${ }^{19}{ }^{19}$ Nokkrir kronikuritarar notuðu orðmyndina aguacate í verkum sínum og gáfu par með tóninn fyrir bað sem sîðar varð en petta er ritháttur orðsins í spænsku nú á tímum. Báđar myndir orðsins, abuacate og aguacate, birtast hér og hvar í textum og frásögnum fram undir miðja 16. öld en á síðari helmingi aldarinnar virðist seinni myndin hafa orðið ofan á. ${ }^{20}$

Degar pessi orðmynd hafði fest sig í sessi í spænsku leið ekki á löngu pangað til hún barst inn í önnur Evrópumál. Elsta heimild um pessa orðmynd í frönsku er frá 1640 en pangað barst hún úr hollensku og spænsku. ${ }^{21}$ Orðmyndin aguacate ${ }^{22}$ hverfur hins vegar úr frönsku máli um miðbik 19. aldar og víkur²3, að pví er virðist, fyrir rithættinum avocate (17. öld), avocata og síđan avocat en sú mynd orðsins er nú notuð í frönsku. Franskir orðfræðingar telja að breytinguna megi rekja til alpýðuskýringa og að avocat sé dregið af spænska orðinu avocado, eða abogado. ${ }^{24}$ Tökuorðið hafi sem sagt

17 Fray Toribio de Benavente o Motolinia, Historia de los indios de la Nueva España, bls. 157. Spænska orðsögubókin gefur upp ritháttinn abacatl í riti Motolinía og markar sem ritháttarafbrigði. DHLE = Diccionario histórico de la lengua española, Madrid: Academia Española, 1933-1936, http://web.frl. es/DH1936.html [sótt 15. ágúst 2018], s. v. aguacate. Sjá einnig CNDH = Corpus del nuevo diccionario histórico del español, http://web.frl.es/CNDHE/ [sótt 15. desember 2018], s. v. aguacate.

18 Fray Toribio de Benavente o Motolinia, Historia de los indios de la Nueva España, bls. 157.

19 Hugo A. Mejías, Préstamos de lenguas indígenas en el español americano del siglo XVII, bls. 40.

20 CORDE.

$21 T L F i=$ Tresor de la langue française, Paris: Gallimard, www.atilf.atilf.fr [sótt 15. desember 2018] s. v. avocat. Alejandro Cioranescu, Los hispanismos en el francés clásico, Madrid: Anejos del boletín de la Real Academia Española, 1987, bls. 20.

22 TLFi, s. v. aguacate.

23 „[...] aguacate, qui a été lui aussi emprunté en français (1640) avant d'être éliminé par avocat“. $D H L F=$ Diccionaire historique de la langue française, ritstj. Alan Rey, Paris: Le Robert, 2006, bls. 276.

24 Pess má geta að $b$ og $v$ er borið eins fram í spænsku (tvívaramælt raddað lokhljóð). 
breyst fyrir áhrif frá orðinu abogado, sem í spænsku merkir ,lögfræðingur' ${ }^{25}$ Svipaðri skýringu bregður fyrir í verkum orðfræðinga víða í Evrópu. ${ }^{26}$ Enskir orðfræðingar telja orðið komið inn í málið í gegnum spænsku, ,avocado, advocate, substituted by 'popular etymology' for the Aztec abuacatl“ og benda jafnframt á að ,a nearer form in Sp. is aguacate F. aguacat and avocat, in Eng. also avigato and, corruptly, alligator (pear)“. ${ }^{27}$ Í enskum texta frá 1676 er avókadó kallað Spanish Pear en pegar líður að aldarlokum koma fyrir orðmyndir eins og albacato, avacado og avacado pear (1696). Í reisubók Williams Dampier, A New Voyage Around the World (1697), ${ }^{28}$ stendur skrifad avogato pear. Avocado kemur svo fyrir í ensku máli undir lok 17. aldar og er sú mynd almennt notuð nú á dögum. ${ }^{29}$ Samkvæmt orðsifjabók Kluge er mynd tökuorðsins í pýsku Avocado en par er samhljómur með frönskum og enskum orðsifjafræðingum hvað varðar mynd og merkingu orðsins, pað er, að pað sé dregið af spænska orðinu avocado/ abogado. Kluge telur orðið hins vegar ekki koma inn í pýskt mál fyrr en á 20. öld, ${ }^{30}$ en pað er fullyrðing sem ætti að taka með varúð. ${ }^{31}$ Tökuorðið kemur fyrir í eldri pýskum textum ${ }^{32}$ með rithættinum

25 TLFi. DHLF, bls. 275-276.

26 Nú má velta vöngum yfir pví hvort um sannfærandi skýringu franskra og annarra evrópskra orðfræðinga sé að ræða par sem orðin eiga merkingarlega ekkert sameiginlegt. Pá má á pað benda að svona er pað allajafna pegar um alpýðuskýringar (etimología popular) er að ræða. Ásta Svavarsdóttir, í pistli um stígvél, útskýrir fyrirbærið á eftirfarandi hátt: „Í málfræði eru ummyndanir af pessu tagi nefndar alpýduskýringar (folk etymology) pví pær verða til við pað að málnotendur leitast við að tengja framandlegar orðmyndir við kunnuglega orðliði og pannig skapast sýndartengsl við alls óskyld orð.“ „Stígvél“ í Orð̈pistlar, Árnastofnun www.arnastofnun.is [sótt 15. desember 2018].

27 OED = Oxford English Dictionary, Oxford: Oxford University Press, 1989, bls. 822.

28 Frances Luttikhuizen, „El viaje de tres voces de lenguas indígenas americanas al inglés: guayaba, aguacate, papaya", De América a Europa. Denominaciones de alimentos americanos en lenguas europeas, ritstj. Erla Erlendsdóttir, Emma Martinell og Ingmar Söhrman, bls. 221-227, hér bls. 217-221.

29 Sama rit.

$30 E W D S=$ Friederich Kluge, Etymologisches Wörterbuch der deutschen Sprache, Berlin, New York: De Gruyter, 1999, bls. 70.

31 Árið 1702 var reisubók Williams Dampier býdd úr frönsku á býsku. Í verki Bretans er minnst á avókadó-ávöxtinn: Avogato-Birn-Baum. „Der Avogato-Birn=Baum ist auch so groß / wie die meisten andern Birn-Bäume [...]“. Sjá William Dampier, Neue Reise Um die Welt: Worinnen umständlich beschrieben wird: Die Erd-Enge oder Isthmus von Americâ, vielerley Küsten und Insuln in WestIndien [...]; Aus dem Englischen in die Frantzösische und nunmehr in die Hoch-Teutsche Sprache übersetzet ..., Leipzig: Rohrlach, 1702, bls. 379.

32 Sjá Georg Friederici, Americanistisches Wörterbuch und Hilfswörterbuch für den Amerikanisten, Hamburg: Cram, De Gruyter \& Co, 1960, bls. 43. 
Avogato-Birnen, ,avókadópera', Advokaten-Birne ${ }^{33}$ og Alligator-Birne ${ }^{34}$ en myndir orðsins í pýsku eru nú Avocado, Avokado eða Avokato. ${ }^{35}$ Danska orðabókin, Den danske ordbog, ${ }^{36}$ telur að avocado, einnig stafsett avokado, hafi komið í dönsku úr spænsku, sem má teljast hæpið ef saga orðsins í málinu er rakin. Orðið kemur vart fyrir í dönskum orðabókum fyrr en með útgáfu á viðauka dönsku orðabókarinnar $(O D S)$ í lok 20. og byrjun 21. aldar. ${ }^{37}$ Par kemur fram að orðið sé fyrst bókfest í málinu árið 1767. Eftir pví sem best verður séð kemur orðið fyrst fyrir í safni með ýmsum ferðasögum, Almindelig Historie over Reiser til Lands og Vands, sem voru pýddar úr ensku á dönsku og gefið út á árunum 1748-1761. Pýðandi verksins var Christen Schmidt (1721-1810). ${ }^{38}$ Í safninu er meðal annars ferðasaga Williams Dampier í danskri pýðingu og aðlögun. Í textanum stendur skrifað: „Dampier admirerer Sapadiller, Avogatos, og Mammets-Sapota, samt Stierneæblerne, saa at han endogsaa giør sig en Pligt af at beskrive dem.“" ${ }^{9} 9$ Á sömu blaðsíðu kemur Avogatotrce fyrir og er pað sagt geta "holdes for et slags Pæretræ“. ${ }^{40}$ Af ofansögðu er ljóst að tökuorðið hefur komið í dönsku úr ensku og að pað á sér aðeins lengri sögu í málinu en fram kemur í dönskum heimildum. ${ }^{41}$ Orðmyndin avokat, ,et slags stor Winterpære“, kemur

33 Advokat merkir, lögfræðingur‘.

34 Tökupýððing úr ensku. Merking orðsins er ,krókódílapera‘ og sprettur af samlíkingu avókadóhýðis við krókódílaskinn.

$35 D F=$ Duden, Das Fremdwörterbuch, Mannheim, Leipzig, Wien, Zürich: Dudenverlag, bls. 98.

$36 D D O=$ Den danske ordbog, s. v. avokado http://ordnet.dk [sótt 15. desember 2018]. Sjá einnig PNOE = Politikens forlag, Politikens Nudansk Ordbog med etymologi, Ålborg: Politikens, bls. 105 (s. v. avocado el. avokado). PEO = Politikens forlag, Politikens etymologisk ordbog, Ålborg: Politiken, bls. 105 (s. v. avocado el. avokado).

37 ODSS = Danske sprog- og literaturselskab, det, Ordbog over det danske sprog. Supplement, København: Gyldendal, 1992-2005, http://ordnet.dk/ods/ [sótt 15. desember 2018], s. v. avokado. Sjá einnig $M F$ = Karl Hårbøl, Jørgen Schack og Henning Spang-Hanssen, Fremmedordbog, København: Munksgaards ordbøger, 1997, bls. 83. Politiken, Politikens nudansk med etymologi, København: Politikens Forlag, 2000, bls. 105.

38 R. Paulli, „C. Schmidt“, Dansk Biografisk Leksikon, 3. útg., København: Gyldendal, 1979-1984, http://denstoredanske.dk/index.php?sideId=297086 [sótt 15. desember 2018].

39 Almindelig Historie over Reiser til Lands og Vands, I-XVIII, København, 1748-1762, hér 1761, bls. 117. Sapadiller (spæ. zapotilla,) og Mammets (spæ. mamey?). Sapota (spæ. zapote, nah. zapotl) er orð úr máli indína í Mexíkó yfir ávöxtinn Pouteria sapota.

40 Sama rit.

$41 O D S=$ Danske sprog- og literaturselskab, det, Ordbog over det danske sprog, København: Gyldendal, 1975, http://ordnet.dk/ods/ [sótt 15. desember 2018]. ODS er söguleg oroabók sem nær yfir tímabilið frá 1700 til 1950. ODSS. 
fyrir í bók franska grasa- og náttúrufræðingsins Valmont de Bomare sem hinn norskættaði Hans von Aphelen pýddi á dönsku og kom ritið út í átta bindum í Kaupmannahöfn á tímabilinu frá 1767$1770 .{ }^{42}$ Avocado eða avokado ${ }^{43}$ eru orðmyndir sem eru notaðar jöfnum höndum í dönsku málsamfélagi nú á dögum og fyrirfinnast í málinu síðan á priðja áratug 20. aldar. ${ }^{44}$ Tökuorðið hefur lagað sig að dönsku málkerfi ${ }^{45}$ og ný orð hafa verið smíðuð par sem indíánaorðið myndar annan liðinn. Auk lýsingarorðsins avokadogron ,avókadógrænn', eru pað samsettu orðin avokadodip og avokadomos fyrir ,avókadóídýfu' og ,avókadómauk، ${ }^{46}$

Samkvæmt orðabók sænsku akademíunnar er advokatpäron, ,avókadópera', elsta ritmynd orðsins í sænsku máli, frá árinu 1875. Sennilega er pessi mynd fengin úr ensku avocado pear eða pýsku Advogatobirne. ${ }^{47}$ Orðið er hins vegar eldra í málinu og dæmi um pað frá seinni hluta 18. aldar pá er pað kemur fyrir með rithættinum avogater í riti C.G.A. Oldendorp sem var pýtt úr býsku og gefið út á árunum 1786-1788. ${ }^{48}$ Í texta Oldendorps stendur skrifað: „Man får (på danska Västindien) avogater, guiave, mispel, frukter [...].““ “99 Núverandi ritmynd orðsins avokado kemur fyrir í sænskum textum frá miðri 20. öld, í fyrstu með rithættinum avocado. ${ }^{50}$ Orðið hefur lagað sig beygingarlega að sænsku máli og er til í bæði eintölu og fleirtölu. ${ }^{51}$ Í sænsku myndar tökuorðið nokkur samsett orð eins og til dæmis avokadoröra ,avókadósósa', avokadogrön ,avókadógrænn‘ og avokadosallad, avókadósalat‘.

42 Valmont de Bomare, Den almindelige Natur-Historie, i Form af et Dictionnaire, Oversat, for $\varnothing$ get og forbedret af H. von Aphelen, 8 bd., København 1767-1770, hér 1767, bls. 158.

$43 D D O$, s. v. avokado.

44 ODSS, s. v. avokado.

45 Sjá $D D O$, s. v. avokado: Í eintölu avokado og avokadoen. Í fleirtölu avokadoer og avokadoerne.

46 Sama rit, s. v. avokado.

$47 S A O B=$ Svenska Akademien, Svenska Akademiens Ordbok över Svenska Språket, Stockholm: Svenska Akademien, 1-30, 1898-1998/99, http://saob.se [sótt 9. desember 2018], s. v. advokatpäron.

48 Seðlasafn Sænsku akademíunnar. C.G.A. Oldendorp, Historisk beskrifning öfver Evangeliske brödernas missionsarbete på Carabiske Öarne St. Thomas, St. Croix och St. Jan, 1-2, Stockholm, 1786-1788.

49 Sama rit.

50 Seðlasafn Sænsku akademíunnar. NEO = Nationalencyklopediens ordbok, Utarbetad ved Språkdata Göteborgs Universitet, Göteborg: Bra Böcker, 2004, bls. 79.

51 Í eintölu er orðið en avokado, og með ákveðnum greini avokadon. Í fleirtölu: avokador og með ákveðnum greini avokadorna. SO = Svensk ordboka, Svenska akademien, https://svenska.se/ [sótt 9. desember 2018], s. v. avokado. 
Norska orðabókin skilgreinir avokado sem „grønn, pæreformet tropisk frukt av avokadotreet" ${ }^{52}$ Önnur heiti yfir ávöxtinn í norsku eru alligatorpare og advocado en samkvæmt SNL eru bæði „avokado og advokat [...] forvanskninger av det aztekiske navnet ahuacatl“".53 Orðið, sem kemur fyrir í norskum textum frá miðri 20 öld ${ }^{54}$, hefur lagað sig að norsku málkerfi (bókmáli og nýnorsku) og er til í eintölu og fleirtölu ${ }^{55}$ og myndar auk pess nokkur samsett orð í málinu, má par nefna m.a. avokadofrukt ,avókadóávöxtur', avokadogrønn ,avókadógrænn', avokadopare ,avókadópera' og avokadotre ,avókadótré‘ ${ }^{56}$

Avocado kemur fyrir í íslenskum textum upp úr miðri 20. öld og er skrifað avókadó í Íslensku alfracðiordabókinni frá 1990 og Íslenskri ordabók frá 2002. ${ }^{57}$ Elsta ritdæmi orðsins, samkvæmt upplýsingum úr ritmálssafni Orðabókar Háskólans, er í Matreiðslubók handa ungu fólki eftir Sigrúnu Davíosdóttur frá árinu 1978. Í bókinni kemur eftirfarandi fram um ávöxtinn: „Avocado er óvenjulega feitur ávöxtur, en fitan er ómettuð og talin frekar heilsusamleg. " ${ }^{8}$ Eldri dæmi um orðið er hins vegar að finna í tímaritum og dagblöðum frá miðri 20. öld. Til að mynda í grein eftir Níels Dungal, sem birtist í tímaritinu Helgafell árið 1955, par sem stendur: „Hér [á Trinidad] vaxa öll möguleg tré, sem tilheyra hitabeltinu, svo sem caruarina, cecropia, brauðaldin [...] auk pess papaya, avocado og mangotré [...]." ${ }^{9}$

Samsetta orðið avocadopera kemur fyrir í tímaritinu Samtídin frá $1963^{60}$ og skömmu síðar í Alfræðasafni AB sem var gefið út á

$52 B O B=$ Universitetet i Bergen/Språkrådet, Bokmålsordboka, 2016, http://www.bob.ordbok.uio.no [sótt 9. desember 2018], s. v. avokado.

$53 S N L=$ Store norske leksikon, https://snl.no [sótt 9. desember 2018], s. v. avokado.

$54 N A O B=$ Det Norske Akademis ordbok, https://www.naob.no [sótt 9. desember 2018], s. v. avokado.

55 Í norsku bókmáli er eintalan: en avokado, avokadoen, og fleirtala: avokadoer og avokadoene. Í nýnorsku er eintala en avokado og avokadoen, og í fleirtölu: avokadoar, avokadoane. BOB, s. v. avokado. NOB = Universitetet i Bergen/Språkrådet, Nynorskordboka, 2016, http://www.nob.ordbok.uio.no [sótt 9. desember 2018], s. v. avokado.

56 BOB, s. v. avokado. NOB, s. v. avokado.

57 ÍO. IAO.

$58 R O H=$ Ritmálssafn Orð̇abókar Háskólans. Stofnun Árna Magnússonar í íslenskum fræðum, www. arnastofnun.is/page/gagnasofn_ritmalssafn [sótt 9. desember 2018]. Seðlasafn Orðabókar Háskólans.

59 Níels Dungal, „Heimsókn í Trinidad“, Helgafell 1, 1955, bls. 102, Landsbókasafn Íslands Háskólabókasafn, Tímarit.is http://timarit.is [sótt 9. desember 2018].

60 „Нvað er munaður?“, Samtíðin 10, 1963, bls. 17. Tímarit.is http://timarit.is [sótt 9. desember 2018]. 
árunum 1965-1968. ${ }^{61}$ Pá voru heimiliseldavélar í ýmsum litum, m.a. avocado-grcenar, auglýstar í blöđum og tímaritum á árunum 1976 og $1977 .{ }^{62}$ Hvað varðar dæmi um ritháttinn avókadó má líta til gagnasafna Stofnunar Árna Magnússonar í íslenskum fræðum, en í Markadri íslenskri málheild (MÍM) eru nokkur dæmi sem sýna mörg hver að heiti aldinsins kemur jafnan fyrir í auglýsingum dagblaða, mataruppskriftum í matreiðslubókum og tímaritum ásamt pví að blasa við viðskiptavinum á matseðlum veitingahúsa og skyndibitastaða. Lesendur dagblaða reka augun gjarnan í umfjöllun af eftirfarandi tagi: „Avókadó er sannkölluð ofurfæða sem er sneisafull af hollri fitu, trefjum og bætiefnum og er pessi púsund ára gamla krókódílapera ein vinsælasta matvaran á Vesturlöndum.“63 Við petta má bæta að fleirtala orðsins skýtur upp kollinum í grein sem birtist í Bandablaðinu árið 2015 en par notar greinarhöfundur orðmyndina avókat og avóköt í fleirtölu. ${ }^{64}$ Samkvæmt Beygingarlýsingu islensks nútimamáls (BÍN) er avókadó hvorugkynsnafnorð. Eintala og fleirtala án greinis er avókadó og með greini avókadóið og avókadóin. ${ }^{65}$

Tökuorðið avókadó hefur borist til Íslands og annarra Evrópulanda í kjölfar pess að mexíkönsk matargerðarlist varð vinsæl og útbreidd um víða veröld. Hvort orðið avókadó heldur velli î íslensku skal látið ósagt, en um pessar mundir togast pað á við tökupýðinguna ${ }^{66}$ lárpera um tilveru sína í málinu.

\subsection{Maís}

Maís er nytjajurt af grasætt (lat. Zea mays) sem gefur af sér gulleit korn. Jurtin er ættuð frá Mið- og Suður-Ameríku en frá örófi alda hefur maísrækt verið almenn á Antillaeyjum í Karíbahafi, í Mexíkó og suður eftir álfunni. Korn plöntunnar var mikilvæg fæða

\footnotetext{
61 ROH.

62 Auglýsing í Vikunni 38 (16)/1976, bls. 8. Tímarit.is http://timarit.is [sótt 9. desember 2018].

63 Brynhildur Björnsdóttir, „Krókódílaperan slær í gegn“, Fréttabladið, 27. júlí 2018, (Kynningarblað), bls. 4. Krókódílapera er tökupýðing úr ensku alligator pear. Hér er um líkingu að ræða.

64 Hafsteinn Hafliðason, „Avókat, avóköt - lárpera, sigurpungur, smjöraldin“, Bandablaðið 29. janúar 2015, http://www.bbl.is/frettir/fraedsluhornid/avokat-avokot---larpera-sigurpungursmjoraldin/5948/ [sótt 9. desember 2018].

$65 B I ́ N=$ Stofnun Árna Magnússonar í íslenskum fræðum, Beygingarlýsing íslensks nútímamáls, ritstj. Kristín Bjarnadóttir, http://bin.arnastofnun.is/forsida/ [sótt 15. desember 2018].

66 Úr pýsku: Laurbirne og Lorbeer-Birne.
} 
í samfélögum frumbyggja í Ameríku en plantan gegndi auk pess pýðingarmiklu hlutverki í trú og menningu indíána.

Maísplantan var meðal ýmissa jurta og afurða frá Vestur-Indíum sem Kólumbus og menn hans höfðu með sér heim til Spánar árið 1493. Nafn plöntunnar barst einnig með landafundamönnum austur um haf, pað er að segja taínskt heiti hennar. Рað kemur fyrst fyrir í leiðarbók sem Kólumbus skrifaði í priðju ferð sinni til Vestur-Indía árið 1498 með rithættinum mahiz ${ }^{67}$ ásamt peirri skýringu að um sé аð ræða einhvers konar korn sem eyjaskeggjar í Karíbahafi noti til brauðgerðar. ${ }^{68}$ Orðið kemur víða fyrir í kronikum sagnaritara, ferðasögum hermanna og ritum trúboða. Hér mætti nefna merka kroniku Pedros Mártir de Anglería ${ }^{69}$ sem var rituð á latínu eftir frásögnum landafundamanna en par er orððð í latneskum búningi: maizium. Pá mætti tilgreina bréf Hernáns Cortés sem voru skrifuð í Mexíkó á árunum 1519 til $1526^{70}$ og skrif Bartolomés de Las Casas frá fyrri hluta 16. aldar. ${ }^{71}$ Fernández de Oviedo fjallar ítarlega um kornið í Indíasögu sem var skrifuð á árunum 1535-1557² og í styttri útgáfu Indíasögunnar, Sumario de la natural historia de las Indias, frá $1526 .{ }^{73}$ Næstu aldir kemur heiti plöntunnar og kornsins fyrir í verkum fjölda annarra spænskra kronikuritara. Í pessum textum er orðið allajafna með rithættinum maís eða maíz og er síðarnefnda orðmyndin notuð í spænsku nútímamáli. ${ }^{74}$ Pessir textar og fleiri voru að hluta til eða að öllu leyti pýddir á önnur Evrópumál pegar á 16. öld og barst orðið í pýðingum norður eftir álfunni.

67 CORDE.

68 Sama rit. Cristóbal Colón, Los cuatro viajes. Testamento, bls. 234.

69 Petrus Martyr Anglerius, De orbe novo Decades. Hér er notast við spænska pýðingu verksins: Pedro Mártir de Anglería, Décadas del Nuevo Mundo, Madrid: Polifemo, 1989 [1516-1530]. Sjá einnig: Erla Erlendsdóttir, ,.,Landa uppleitan og ókunnar siglingar“. Um landafundina og Nýja heiminn í evrópskum skrifum“, Ritið 3/2011, bls. 119-149, hér bls. 126-128.

70 Hernán Cortés, Cartas de relación, ritstj. Ángel Delgado Gómez, Madrid: Clásicos Castalia, 1993. Erla Erlendsdóttir, ,,,Landa uppleitan og ókunnar siglingar““”, bls. 140-141.

71 Bartolomé de Las Casas, Historia de las Indias, ritstj. Carlo Agustín Millares, México/Buenos Aires: Fondo de Cultura Económica, 1965. Sjá einnig María Antonieta Andión Herrero, Los indigenismos en la Historia de las Indias de Bartolomé de Las Casas, Madrid: Gredos, 2004.

72 Gonzalo Fernández de Oviedo, Historia general y natural de las Indias, ritstj. Juan Pérez de Tudela Bueso, Madrid: Biblioteca de autores españoles, 1992 [1535-1557].

73 Gonzalo Fernández de Oviedo, Sumario de la natural historia de las Indias, ritstj. José Miranda, México: Fondo de Cultura Económica, 1996 [1526].

74 CORDE. DRAE = Real Academia Española, Diccionario de la lengua española, Madrid: Espasa, 2014, http://dle.rae.es/ [sótt 15. desember 2018], s. v. maíz. 
Upp úr aldamótunum 1500 var maís víða ræktaður á Íberíuskaga og stuttu sîðar náði útbreiðsla hans til nágrannaríkja Spánar. Að nokkrum öldum liðnum var jurtin ræktuð til skrauts í görðum hefðarfólks í Mið- og Norður-Evrópu, auk pess sem hún var notuð sem dýrafóður. Vitað er með vissu að á 19. öld var maís notaður til manneldis og má nefna sem dæmi að á seinni hluta 19. aldar var bakað maísbrauð úr maísdeigi ${ }^{75}$ á Íslandi, og á fyrri hluta 20. aldar voru par einnig bakaðar maíslummur. ${ }^{76}$ Má segja að nú á dögum sé maís hluti af daglegu lífi fólks í Evrópu. Margir byrja daginn með pví að fá sér kornflögur (maísflögur) í morgunverð, tortillur úr maís með salsasósu og gómsætri fyllingu hafa verið vinsælar undanfarin ár, að ekki sé minnst á hið sígilda poppkorn, „,blásinn maís“, ${ }^{77}$ og maískólfa.

Í Evrópu hefur maísinn gengið undir ýmsum nöfnum, til að mynda „hveiti“ eða „korn frá Indíum“, „indíánakorn“, „tyrkneskt korn“, „tyrkneskt hveiti“, „korn frá Tyrklandi“, svo einhver séu nefnd. ${ }^{78}$ Sambærileg heiti koma fyrir í ýmsum norrænum heimildum frá fyrri öldum, meðal annars íslenskum, ásamt sjálfu heitinu maís.

Orðið maíz barst úr spænsku yfir í ítölsku í kringum 1518$1519^{79}$ og er í dag ritað màis. ${ }^{80}$ Mä̈s kemur fyrir í frönskum textum frá um 1525 en kom inn í málið úr spænsku og ítölsku. ${ }^{81}$ Í pýskum texta frá 1520 kemur fyrir orðmyndin machiz, ${ }^{82}$ en frá 16. öld hefur ritháttur orðsins verið Mais. ${ }^{83}$ Fyrsta heimild um orðið í ensku er frá árinu 1555 en pá kom út fyrrnefnd kronika Pedros Mártir de

$75 \mathrm{ROH}$.

76 Sama rit.

77 ROH: Sjá Helga Sigurðardóttir, Matur og drykkur, Reykjavík; Ísafold, 1966, bls. 479.

78 Hér í íslenskri býðingu. Sjá til dæmis türkisch Korn, indianischer Weizen og indianisches Korn í pýsku (Philip M. Palmer, Nenweltwörter im Deutschen, Heidelberg:Carl Winter's Universitätsbuchhandlung, 1939, bls. 89). Blé d'Espagne, blé d'Inde og blé de Turquie í frönsku (TLFi). Indisk korn, indianisk korn, välsk korn, indiskt vete og indiansk vete í sænsku (SAOB).

79 Marco Mancini, L'esotismo nel lessico italiano, Viterbo: Università degli studi della Rusca. Istituto di studi romanzi, 1992, bls. 141.

$80 E V L I=$ Alberto Nocentini, l'Etimologico. Vocabolario della lingua italiana, Milano: Le Monnier, 2010, bls. 658. Samheiti er granoturco.

$81 T L F i$, s. v. maïs. Cioranescu, Los hispanismos en el francés clásico, bls. 182. Fræðimönnum ber ekki saman um ártalið. Cioranescu segir elsta dæmi orðsins vera frá 1522.

82 Palmer, Neuweltwörter im Deutschen, bls. 89. Christine Henschel, Italienische und französische Reiseberichte des 16. Jahrbunderts und ibre Übersetzungen. Über ein vernachlässigtes Kapitel der europäischen Übersetzungsgeschichte, Darmstadt: Wissenschaftliche Buchgesellschaft, 2005, bls. 285.

83 Palmer, Neuweltwörter im Deutschen, bls. 89. 
Anglería í enskri pýðingu Richards Eden. ${ }^{84}$ Orðið kemur fyrir með rithættinum maizium eins og í latneska frumtextanum en hefur alla jafna verið ritað maize frá árinu 1585.85 Á svipuðum tíma kemur orðið fyrir í hollenskum textum. ${ }^{86}$

Í dönsku lesmáli frá seinnihluta 16. aldar og frá 17. öld koma fyrir heitin tyrkisk korn og indiansk eða indisk korn ${ }^{87}$ sem gefur vísbendingu um að afurð maísplöntunnar hafi verið mönnum kunn í Danmörku á pessum tíma. Elstu dæmi pessara heita er að finna í ýmsum býðingum, vísinda- og náttúruritum, en auk pess koma pau fyrir í orðabókum og alfræðiritum. Í orðabókarhandriti Matthiasar Moth frá aldamótunum 1700 er til dæmis tyrkisk korn og tyrkisk bvede. ${ }^{88} \mathrm{Og}$ Kalkar tiltekur indisk korn, tyrckesk ru og indiske-korn í orðabók sinni. ${ }^{89}$

Líklegt má telja að mahis hafi borist í dönsku úr býsku á fyrri hluta 17. aldar en elsta dæmið um orðið kemur fyrir í prentaðri bók frá 1641 sem Hans Hansen Skonning,,$^{90}$ prentari og hringjari í Árósum, tók saman úr ýmsum pýskum bókum og skrifum frá 16. öld og byrjun 17. aldar, eins og hann getur um verki sínu. Í bók Hansens Skonning, í kafla sem fjallar um frumbyggja í Nýja heiminum, stendur meðal annars að mays sé „it slags fruckt“ (544) og á öđrum stað í bókinni er sagt frá pví að frumbyggjar búi til kökur úr „Mays (it slags korn)“ (534). Á fyrsta áratug 18. aldar koma orðmyndirnar maitz og mais fyrir í ferðasögum og verkum býddum úr ensku og frönsku; núverandi ritháttur orðsins er svo majs en elsta

84 Peter Martyr, Decades of the New World of West India, London, 1555.

85 OED.

86 GWNT $=$ Groot Woordenboek van de Nederlandse Taal, ritstj. Dirk Geeraerts Ton den Boon, Utrecht/ Antwerpen: Van Dale Lexicografie, 2005.

87 ,Tyrkneskt korn`, ,korn frá Indíum‘. Kornið var kennt við pað sem menn héldu vera upprunaland pess. Í Tyrklandi kallast maísinn aftur á móti egypskt korn. Sjá Nesrin Karavar, „Alimentos comunes desde Latinoamérica a Turquía“, ritstj. Erla Erlendsdóttir, Emma Martinell og Ingmar Söhrman, De América a Europa, bls. 350.

88 Matthias Moth, Motbs Ordbogen. Historisk ordbog ca 1700, København: DSL, https://mothsordbog. dk [sótt 15. desember 2018], s. v. tyrkisk.

89 Otto Kalkar, Ordbog til det celdre danske sprog (1300-1700), København, 1881-1907, https:// kalkarsordbog.dk/ [sótt 15. desember 2018], s. v. indisk, tyrcesk.

90 Hans Hansen Skonning, Geographia Historica Orientalis. Det er Atskillige Østerske Landis oc Øers / met deß Folcis Beskriffvelse: Nemlig / Tyrckers / Jøders / Grokers / Egypters / Indianers / Persianers / oc andre flere Landskabers underlige Sader / Tro / Religion / Lower oc selsom Lands Maneer, Århusz, 1641. 
dæmið um hann er frá byrjun 19. aldar. ${ }^{91}$ Í lokin má geta pess að orðið hefur aðlagast viðtökumálinu bæði hljóðfræði- og beygingarfræðilega, ${ }^{92}$ og hafa allmörg samsett orð verið smíðuð par sem majs myndar annan liðinn, svo sem majsdyrkning ,maísrækt', majsbrandevin ,maísbrennivín', majskolbe ,maískólfur', majskorn ,maískorn' og majsgul ,maísgulur'.93

Í sænsku er maíss fyrst getið í textum frá 17 . öld, til dæmis bréfum, ritum um landbúnað og ýmsum skrifum í Nýju Svípjód, nýlendu Svía á austurströnd Bandaríkjanna. ${ }^{94}$ Í fyrstu voru orðasamböndin indisk korn, indianisk korn, välsk korn, indiskt vete, indiansk vete og fleiri notuð í sænsku til að nefna jurtina. Elsta ritdæmið er frá 1640 en pá kemur orðið fyrir í bréfum og skrifum kansellíráđsins Axels Oxenstierna með rithættinum macis. Á tímabilinu frá $1644^{95}$ til 1786 birtist orðið í ýmsum ritum með mismunandi rithætti eins og venja er um orð sem ekki hafa aðlagast viðtökumálinu. Má par nefna magis, maiis, maijs og maijss og merkingin er almennt ,plantan Zea mayss. Ennfremur eru mais og mays orðmyndir sem koma fyrir í ýmsum sænskum textum frá 1671 og fram á 19. öld. Í dag er ritháttur orðsins majs og hefur verið allar götur frá $1806 .{ }^{96}$ Orðið hefur aðlagast sænsku málkerfi ${ }^{97}$ og pví til vitnis eru meðal annars mýmörg samsett orð í málinu par sem tökuorðið er fyrri liðurinn. Sem dæmi má nefna: majsbrännvin ,maísbrennivín', majsgröt ,maísgrautur', majskaka ,maískaka', majskolv ,maískólfur', majsmjöl ,maísmjöl', majssocker ,maíssykur' og majsvete ,maíshveiti ${ }^{98}$

Í Noregi kemur heitið yfir korntegundina fyrir í bók um landbúnað frá 1776 en par stendur skrifað „mais eller tyrkisk hvete“.99

91 ODS, s. v. majs.

92 Sjá DDO, s. v. majs: orðið er í óákveðnum hætti eintölu en majs, í ákveðnum hætti eintölu majsen, í fleirtölu óákveðnum hætti majs og í ákveðnum hætti majsene.

93 Sjá til dæmis ODS og DDO, s. v. majs.

94 Nya Sverige var á svæði par sem Delaware, Pennsylvania, New Jersey og Maryland eru í dag.

95 Árið 1644 kemur orðið fyrir í skýrslu Johans Printz, ríkisstjóra sænsku nýlendunnar í Ameríku. $S A O B$, s. v. majs.

96 SAOB.

97 Orðið er í eintölu óákveðnum hætti en majs og í ákveðnum hætti majsene. Pað er ekki til í fleirtölu. SO.

98 SAOB.

99 Anders Christensen, „Nissen om humledyrkning“, http://anders.geekhouse.no/blog/2015/12/index. html. Martinus Nissen, Theoretiske og practiske Underratninger om Agerdyrkningen med meere, som Til Landvasenet henhorer, Deels ag de boste Autores utdragne og deels ved lang Øvelse samlede og forsøgte, bestaaende af 28 Kapitler, Sammenskrevne og til Trykken befordrede til Landmandens Nytte ved Martinus Nissen, 
Samkvæmt upplýsingum úr seðlasafni Háskólans í Oslón ${ }^{100}$ er elsta ritdæmið með mais í bókmálsnorsku frá seinni hluta 18. aldar og kemur fyrir í tímaritinu Topografisk Journal frá árunum 1796 til 1798. Af ofansögðu má ætla að jurtin, afurðin og heitið hafi verið pekkt í Noregi á ofanverðri 18. öld, jafnvel fyrr. Orðið kemur fyrir í ýmsum textum á nýnorsku frá 19. öld. ${ }^{101}$ Samkvæmt norskum heimildum kom orðið inn í málið í gegnum spænsku ${ }^{102}$ en líklegra má telja að pað hafi borist inn í norsku um nágrannamálin, dönsku og sænsku, vegna nábýlis og tengsla landanna. Tökuorðið hefur lagað sig að málkerfi norskunnar. ${ }^{103}$ Í málinu finnast einnig samsett orð með mais, til að mynda maisplante ,maísplanta‘, maiskolbe ,maískólfur' og maismel ,maísmjöl'". ${ }^{104}$

Í íslenskum heimildum frá 18. öld eru dæmi um heitin tyrkneskt bveiti, tyrkneskt korn og indiskt bveiti, og orðið maís kemur jafnvel fyrir í einstaka texta. Petta gefur tilefni til að draga pá ályktun að Íslendingar hafi pekkt til kornsins á pessum tíma. Samkvæmt $R O H$ kemur indíanaorðið fyrst fyrir í íslenskum texta frá 1756 með rithættinum mahis. Í umræddum texta, sem er pýðing úr dönsku, ${ }^{105}$ er orðið útskýrt sem „Tyrkneskt korn“. ${ }^{106}$ Í Riti pess Islendska Loerdóms-Lista Felags, tímariti frá seinni hluta sömu aldar, er talað um tyrkneskt hveiti eins og sjá má í textabrotinu sem hér fylgir: „Vestan úr heimi høfum ver pat miølgresi fengit, er Mays eda Tyrkneskt Hveiti er nefnt. “107 Árið 1821 skrifar Magnús Stephensen að „peir lifdu á Indískri Korntegund, er nefnist Mays“. ${ }^{108}$ Að lokum má nefna handrit í handritasafni Konunglegu bókhlöðunnar í

Commerce-Secreterer, Trondhiem, 1776. Trykt hos Jens Christensen Winding paa Autors Bekostning.

$100 N L I=$ Norsk Leksikografisk Institut, Osló.

101 Sama heimild.

102 NOB, s. v. mais. BOB, s. v. mais.

103 Í norsku bókmáli: í óákveðnum hætti eintölu en mais, og í ákveðnum hætti maisen; í fleirtölu maiser og maisene. Í nýnorsku er pað en mais í eintölu óákveðnum hætti og í ákveðnum hætti maisen; í fleirtölu óákveðnum hætti maisar og í ákveðnum hætti maisane. Sömu rit.

104 Sömu rit.

105 ROH: Dess Svenska Gustav Landkrons Og Pess Engelska Bertholds Faabreitileger Robinsons, Edur Lijfs og Afe Søgur, Ur Dønsku wtlagdar Af Sr. Porsteine Ketels Syne, bls. 309.

106 Sama rit.

$107 \mathrm{~V}$, bls. 13 .

108 ROH: Utvaldar Smá-Søgur, Almenníngi til Fródleiks og Skémtunar. ... I. Bindis 1.-2. Hefti, bls. 101. 
Kaupmannahöfn, pýðingu á áđurnefndri bók Hansens Skonning ${ }^{109}$ sem kom út í Árósum árið 1641. Handritið er dagsett 1676 og er par með elsta íslenska heimildin um orðið. Í kafla sem fjallar um indíána í Nýja heiminum stendur: „Peir hafa eitt slags Rúg, sem peir neffna Maiz, sumir kalla pad Gvÿenisktt Korn." ${ }^{110}$ Á 19. og 20. öld birtist orðið til að mynda með rithættinum mais, moes, majs og maís, og er sîđastnefndi rithátturinn nú almennt notaður í íslensku. ${ }^{11}$ Orðið hefur lagað sig að íslensku málkerfi ${ }^{112}$ og myndar hluta af allmörgum samsettum orðum sem eru notuð í daglegu tali, til dæmis maísbaunir, maískólfur, maísmjöl og maíspoki. ${ }^{113}$

\section{Lokaorð}

Hér að framan hefur verið rætt um tvö orð af erlendum toga sem hafa skotið rótum í íslensku og nokkrum öðrum Evrópumálum. Orðin, sem núna eru góður og gildur hluti af orðaforða flestra viðtökumálanna, koma langt að: pau eru ættuð úr taíno og nahuatl, tungumálum frumbyggja í Ameríku. Avókadó og maís eru nafnorð og heyra undir merkingarsviðið nytjajurtir. Á sínum tíma voru pessi orð hrein viðbót við orðaforða flestra viðtökumálanna og ógnuðu par af leiðandi ekki erfðarorðum í málunum og riðluðu ekki heldur merkingarskipan hugtaka og heita í tungumálunum. Pau hafa í flestum tilfellum lagað sig að hljóð- og beygingarkerfi viðtökumálanna en pví er pó ekki að neita að avókadó hefur yfir sér framandlegan blæ og má pað ef til vill rekja til endingar orðsins. Hvað varðar merkingu orðanna pá hefur hún haldist óbreytt og kemur svo sem ekki á óvart par sem um er að ræða nafnorð með hlutlæga merkingu.

Avókadó ber með sér að hafa haft viðdvöl í öðrum tungumálum á ferð sinni milli mála í Evrópu pótt merking orðsins hafi ekki

109 Hans Hansen Skonning, Geographia Historica Orientalis. Austur Landa og Eya með peirra foolke, Einkum Tyrkia, Gyðjinga, Gryckia, Egypta, Indiana, Persa - og Margra fleyre Landa Undarleiger Sider, Trú, Religio, Laúg og Landshatter, 1676, handrit NKS $3664^{\circ}$. Ekki er vitað hver pýddi.

110 Hans Hansen Skonning, Geographia Historica Orientalis, 1676, $219 \mathrm{r}$.

$111 I ́$ IO, bls. 954 . ÍSO = Íslensk stafsetningarorłabók, ritstj. Dóra Hafsteinsdóttir. https://snara.is [sótt 15. desember 2018], s. v. maís.

112 Í eintölu án greinis maís og með greini maísinn. Orðið er ekki notað í fleirtölu eins og oft er um orð sem vísa til einhvers sem ekki er teljanlegt, eins og til dæmis mjólk, kakó, sykur og bveiti. BÍN, s. v. maís.

113 ROH. 
hróflast. Eins og áđur er getið var ritháttur nahuatl-orðsins abuacatl, abuacate og aguacate í spænsku. Síðar er að sjá sem orðið sæti formbreytingum, fyrir áhrif frá orðmyndinni abogado, í munni alpýðunnar á Spáni og var um tíma ritað avocado og abogado sem eru orð af allt öðrum meiði. Fyrra orðið er lýsingarháttur pátíðar af sögninni avocar ,áfrýja‘ (advocãre á latínu) og seinna orðið pýðir ,lögmaður' (advocātus á latínu). Í spænsku hélt eldra formið, aguacate, velli, svo ekki er neinum vafa undirorpið um hvað er að ræða pegar ávöxtinn ber á góma hjá málhöfum. Í frönsku aftur á móti deilir orðið avocat ,avókadó‘ ytra formi með avocat, lögmaður . ${ }^{114}$ Hvað snertir ensku pá er óhætt að segja að ritháttur orðins hafi verið mjög á reiki um langan aldur par til á fyrri hluta 20. aldar að orðmyndin avocado varð ofan á en um skeið var advocat einnig notað í málinu. ${ }^{115}$ Sama er uppi á teningnum í pýsku par sem orðmyndin Avokado (Avocado eða Avokato) stjakaði út öðrum orðmyndum, eins og til dæmis Advokaten-Birne, og festi sig í sessi. Umrædd mynd orðsins barst sîðar yfir í íslensku, avókadó, og önnur norræn mál, avocado eða avokado, á 20. öld. Eins og áđur hefur verið getið eru til eldri dæmi um orðið í dönsku og sænsku, t.d. avogato, avokat, advokat ${ }^{116}$, ritmyndir sem bera pess merki að hafa borist inn í málin úr ensku, frönsku eða pýsku. Helst lítur út fyrir að spænska ritmyndin abogado hafi orðið ofan á og að paðan sé núverandi mynd orðsins komin í ensku og pýsku. Líklegt má telja að ritmyndin avocado í Norðurlandamálunum sé fengin úr ensku.

Elstu rituðu heimildir orðsins abuacatl í spænsku eru frá fyrri hluta 16. aldar. Franska tekur orðið aguacate úr hollensku sem fékk pað aftur á móti úr spænsku á fyrri hluta 17. aldar. Undir lok 17. aldar kemur orðið fyrir í enskum textum og frá byrjun 18. aldar er fyrsta bókfesta orðsins í pýsku. Tökuorðið kemur fyrst fyrir í pessum tungumálum í pýðingum á ferðasögum. Sama er uppi á teningnum í dönsku og sænsku en par eru elstu ritdæmi orðsins frá 18. öld. Avocado kemur ekki fyrir í norsku og íslensku fyrr en á 20. öld og elstu dæmi um orðið er allajafna að finna í ýmsum tímaritum, dagblöðum og matreiðslubókum.

114 DHLF.

115 Frances Luttikhuizen, „El viaje de tres voces de lenguas indígenas americanas al inglés: guayaba, aguacate, papaya", bls. 221.

116 SAOB. ODSS. 
Prátt fyrir að eiga að baki langt ferðalag hefur taínska orðið maís lítið sem ekkert breyst að formi til í viðtökumálunum (spænska maíz, ítalska màis, franska maïs, pýska Mais, danska majs, sænska majs, norska mais, íslenska maís) og merkingin er í öllum tilfellum sú sama og upprunaleg merking orðsins í upprunamálinu. Раð er viðbúið að framburður orðsins í hinum ýmsu viðtökumálum sé frábrugðinn upprunalegum framburði taíno-orðsins sem samkvæmt spænskum og spænsk-amerískum fræðimönnum gæti hafa verið /mahiz/ ef litið er til fyrsta ritdæmis orðsins í skrifum Kólumbusar og Las Casas. Hér er hins vegar um vangaveltur að ræða. Eins og áður var vikið að er hvort tveggja, ritháttur og hljóðfræðileg gerð orðanna, í raun og veru spænskt og pau voru, að segja má, í spænskum búningi pegar pau bárust inn í önnur tungumál og pannig voru pau allt par til pau féllu að málkerfi og ritvenjum viðtökumálanna.

Elstu rituðu heimildir orðsins mabiz í spænsku eru frá lokum 15. aldar. ${ }^{117}$ Á fyrri hluta 16. aldar barst orðið úr spænsku yfir í ítölsku, frönsku, býsku og ensku. Elstu ritdæmi um pað koma alla jafna fyrir í bréfum, ferðasögum eða kronikum, textum sem voru upphaflega pýddir úr spænsku eða latínu. Ef litið er til Norðurlandanna pá kemur orðið fyrir í dönskum, sænskum og íslenskum textum frá 17. öld. Í dönsku kemur orðið fyrst fyrir í bókinni Historia Geografica Orientalis eftir Hansen Skonning en hann mun hafa stuðst við pýskar heimildir við ritun hennar. Og í íslenskri pýðingu pessa verks, sem er í handriti í Konunglegu bókhlöðunni í Kaupmannahöfn, er elsta dæmi um orðið í íslenskum texta. Elsta ritdæmið um orðið í sænsku fyrirfinnst í bréfum og skrifum kansellíráðsins Axels Oxenstierna. ${ }^{118}$ Ekki er ólíklegt að orðið hafi borist í sænskt mál í gegnum býsku. ${ }^{119}$ Pá var orðið tekið upp í norsku upp úr miðri 18. öld. Má gera pví skóna að orð¡ð hafi borist úr dönsku í íslensku og einnig í norsku, en hafa ber í huga að Ísland og Noregur voru nýlendur Dana í pá tíð og tengsl landanna eðlilega mikil af peim sökum.

Orðin sem hér voru til umfjöllunar bárust, eins og títt er um flökkuorð, land úr landi og úr einu tungumáli í annað. Ferðalag orðanna hófst í samfélögum frumbyggja spænsku Ameríku á 15.

117 CORDE.

118 SAOB, s. v. advokatpäron.

119 Sama rit. 
og 16. öld, paðan bárust pau vestan um haf til Suður-Evrópu og sîðan norður eftir álfunni til Norðurlanda. Maís barst yfir í dönsku, sænsku og íslensku á 17. öld; norska tók pað upp rúmlega öld sî̉ar. Avókadó er að finna í dönskum og sænskum skrifum frá 18. öld og tæplega tveimur öldum síðar skaut orðið upp kollinum í norsku og íslensku. Núna hafa pessi frumbyggjaorð frá spænsku Ameríku komið sér prýðilega fyrir í viðtökumálunum og virðast komin til að vera, um sinn að minnsta kosti. 


\section{Avókadó og maís \\ Orð með rætur í frumbyggjamálum spænsku Ameríku}

Avókadó og maís eru nytjaplöntur sem bárust með landafundamönnum og landkönnuðum frá Vestur-Indíum til Gamla heimsins í lok 15. og á fyrri hluta 16. aldar. Ekki leið á löngu uns Evrópubúar tóku að rækta plönturnar og neyta ávaxtanna sem hétu sama nafni á viðtökumálunum og upprunamálunum. Maís er úr tungumáli indíána á Stóru-Antillaeyjum í Karíbahafi. Avókadó er heiti sem á ræur í nahuatl, máli indíána í Mexíkó. Orðin sem um ræðir eiga að baki langt ferðalag frá Vestur-Indíum til Suður-Evrópu og paðan norður eftir álfunni til Norðurlandanna. Hér er fjallað um pessi tökuorð í íslensku og öðrum Evrópumálum.

Lykilorð: Tökuorð - indíánamál Ameríku - Evrópumál 


\author{
ABSTRACT \\ Avocado and maize. \\ Words with roots in the indigenous \\ languages of Spanish America
}

Avocado and maize are New World crops that were brought by Spanish conquistadors and explorers from the New World to Europe from the end of the 15th and into the 16th centuries. Soon after, the Europeans themselves started to grow these crops and consume their produce, but retained their indigenous names. The term maize comes from Taíno language that was spoken in the Antilles. Avocado is a term borrowed from nahuatl which was spoken in Mexico. The loanwords discussed in this article passed from the New World to Southern Europe and from the south to the north of the continent. The aim of this paper is to explore these loanwords in Icelandic and other European languages.

Keywords: Loanwords - Amerindian languages - European languages 